\title{
The Effect of Self Efficacy, Time Budget Pressure and Audit Experience on Audit Judgment with Task Complexity as Moderating Variable
}

\author{
Jenny Tandean ${ }^{1}$, Gagaring Pagalung ${ }^{2}$, Syamsuddin ${ }^{3}$ \\ ${ }^{1,2,3}$ Faculty of Economic and Business, Hasanuddin University, Makassar, Indonesia. \\ Corresponding Author: Jenny Tandean
}

DOI: https://doi.org/10.52403/ijrr.20220144

\begin{abstract}
The aims of this study are to determine and analyze the effect of (1) Self efficacy on audit judgment, (2) Time budget pressure on audit judgment, (3) Audit experience on audit judgment, (4) Task complexity moderates the effect of self efficacy on audit judgment, (5) Task complexity moderates the effect of time budget pressure on audit judgment, (6) Task complexity moderates the effect of audit experience on audit judgment.

This research is a type of quantitative research. In this study using attribution theory and social cognitive theory. The population in this study are the auditors in the inspectorate of West Sulawesi Province. The sample determination in this study used census method. The data consisted of primary data obtained using questionnaire and secondary data. The results showed that self efficacy, time budget pressure and audit experience had a positive and significant effect on audit judgment. Task complexity does not moderate the correlation between self efficacy on audit judgment. Task complexity moderates the correlation between time budget pressure on audit judgment. Task complexity moderates the correlation between audit experience on audit judgment.
\end{abstract}

Keywords: Audit judgment, Self efficacy, Time budget pressure, Audit experience, Task complexity

\section{INTRODUCTION}

The role of internal auditors is very important and really needed, because they are considered as the defence party capable of preventing and taking action against irregularities that exist in government agencies. In the world of accounting, the government must be able to provide responsibility in the financial management of the central government and regions to realize good governance characterized by accountability and transparency. Government with management good finance can be seen after the accountability and audit functions public sector financial reporting is going well. A clean government is characterized by accountability, including transparency of financial reports to all parties, including the public. Financial statements can be said to be of high quality in every information if it has been through an examination process by an auditor. Then, the inspectorate as the government's internal supervisory apparatus reviews the financial and performance reports in order to ensure the reliability of the information presented.

Audit judgment is one of the perspectives or considerations made by the auditor to determine an opinion regarding the results of the audit that has been carried out based on the available evidence.

Based on data from the BPK RI that until 2019 the quality of LKPD in general has increased, it means that the WTP opinion is achieved by all provincial government financial reports in Indonesia. As the opinion of the WTP increases, the number of corruption also increases. Based on ICW's findings, in 2020 the number of 
corruption cases was 444 cases and 875 suspects with state losses doubled from the previous period, which was Rp. 18.6 billion. This finding shows how fragile the oversight of government budget management is Corruption cases can be carried out by irresponsible persons. Such as the corruption case by the former Head of the West Sulawesi PUPR Service, namely the corruption case of increasing the Sultambung-Urekang Road, for granting approval on applications for project advance payments that are not in accordance with the system and procedures. The inspectorate as a regional supervisor is responsible for contributing to the fight against corruption auditors inspectorate as the front line in preventing corruption in the public sector must have adequate competence. Auditors in examining related information must determine the appropriate audit judgment because errors in determining audit judgment can lead to audit failure. The case of failed audits in Indonesia was caused by the auditor's lack of appropriate judgment, and it affected the accuracy of giving the final opinion regarding the fairness of the financial statements which caused the audit to fail. Auditors are faced with different situations and conditions in making judgments or audit considerations, starting with audit work that has different levels of complexity. Meyer in (Yusrianthe, 2015) states that audit judgment is influenced by many factors, both technical and nontechnical.

Several factors that influence audit judgment examined in this study are selfefficacy, time budget pressure, and audit experience. Auditors are faced with complex, many, different and interrelated tasks. The high complexity of this audit can cause accountants to behave dysfunctionally, causing an auditor to be inconsistent and not accountable. Therefore, the researcher is interested in conducting a study entitled the effect of self-efficacy, time budget pressure and audit experience on audit judgment with task complexity as a moderating variable.
The purpose of this study based on the formulation of the problem above is to determine and analyze the effect of 1) Self efficacy on audit judgment, 2) Time budget pressure on audit judgment, 3) Audit experience on audit judgment, 4) Task complexity moderates the effect of self efficacy on audit judgment, 5) Task complexity moderates the effect of time budget pressure on audit judgment, 6) Task complexity moderates the effect of audit experience on audit judgment.

\section{LITERATURE REVIEW Attribution Theory}

According to Fritz Heider as the originator of attribution theory said that attribution theory is a theory that explains a person's behavior. In general, attribution theory emphasizes how individuals interpret events and how this relates to their thinking and behavior. Attribution theory refers to how a person explains the causes of the behavior of others or himself whose causes themselves can be from internal factors or external factors.

\section{Social Cognitive Theory}

Social cognitive theory is a theory related to human agency that most human learning occurs in a social environment. By observing what other people do, skills and attitudes. Individuals also see and learn the appropriateness of the observed behavior, then they act according to beliefs about their abilities and the expected results of their actions. According to (Albert Bandura, 1982) that there are elements that come from the learner himself, namely "sense of self-efficacy". Sense of self-efficacy is the learner's belief that he or she can master the knowledge and skills according to applicable standards.

\section{Audit judgment}

Audit judgment is a personal consideration or the auditor's perspective in responding to information that affects the documentation of evidence and the decision making of the auditor's opinion on the financial statements of an entity. Audit 
judgment is necessary because the audit is not carried out on all evidence. An auditor will consider and also choose which audit evidence to use, because the audit process is not carried out on all existing evidence. The auditor will select evidence that is suspected of being wrong. This evidence is used as consideration for the auditor to express an opinion on the results of the audit

\section{Self efficacy}

Self efficacy is the perception/belief that exists within a person towards the abilities he has. Bandura (1997) reveals that self-efficacy is an assessment of selfconfidence about how well individuals can perform the necessary actions related to prospective situations. An auditor must have the ability and confidence in himself to plan and carry out actions that lead to the achievement of goals

\section{Time budget pressure}

Time budget pressure is a condition that shows the auditor is required to make efficiency with the time that has been set. According to (Nirmala \& Nur, 2013), Time Budget Pressure is a condition that shows the auditor is required to make efficiency of the time budget that has been prepared or there are very tight and rigid budgetary restrictions.

\section{Audit experience}

According to Foster (2013: 40) states that experience is a measure of the length of time or period of work that a person has taken in understanding the tasks of a job and has carried it out well. Experience can deepen and broaden one's ability to do a job. Experience is also a learning process and the addition of one's potential development from both formal and non-formal education.

\section{Task complexity}

Task complexity is an unstructured task, difficult to understand and ambiguous (Puspitasari, 2011). Auditors are always faced with many, different, and interrelated tasks. The complexity of a job is also considered to be able to influence a person in carrying out tasks and affect the quality of his work (Tan and Alison, 1999).

\section{MATERIALS \& METHODS}

This study used a quantitative approach. This research includes correlational descriptive research. Research that seeks to reveal a correlative relationship or cause and effect (causal) between the influence of the dependent and independent variables. The analysis technique uses multiple linear regression analysis which is expressed in a mathematical relationship regarding the effect of self-efficacy, time budget pressure $\&$ auditor experience on audit judgment with task complexity as a moderating variable. This research was conducted at the Inspectorate of West Sulawesi Province. The population in this study is the State Civil Apparatus, totalling 73 people. The sampling technique in this study used the census method that is distribution of questionnaires to all populations amount 73 people. There are 2 types of data used in this study, that are primary data and secondary data. The method of data collection in this study was using a questionnaire distributed to all government internal control officers at the West Sulawesi provincial inspectorate office which was carried out for approximately 1 month.

This research uses SPSS (Statistical Package for the Social Science) for data processing. The analysis and test carried out in this study were descriptive statistic, classical assumption test (normality test, multicollinearity test, heteroscedasticity test, and autocorrelation test).

\section{RESULT}

The analytical method used to test a hypothesis in this study is to use Moderate Regression Analysis (MRA). Multiple analysis carried out with two stages of testing. The first stage is multiple regression which is carried out without moderating variables. The second stage is the regression which is carried out with the moderating variable of task complexity. 
A. The results of the analysis without moderating variables

\begin{tabular}{|l|c|c|c|c|}
\hline Variabel Independen & Koefisien & $\mathrm{t}$ & Sig. & Keterangan \\
\hline Konstanta & 1,861 & 5,872 & & \\
\hline Self-efficacy (X1) & 0,086 & 4,423 & 0,000 & Signifikan \\
\hline $\begin{array}{l}\text { Time Budget Pressure } \\
\text { (X2) }\end{array}$ & 0,142 & $-2,231$ & 0,029 & Signifikan \\
\hline Pengalaman Audit (X3) & 0,114 & 3,003 & 0,004 & Signifikan \\
\hline \multicolumn{5}{|c|}{$\begin{array}{c}\alpha=5 \%=0,05 \\
\mathrm{R} \text { square }=0,587\end{array}$} \\
\hline \multicolumn{4}{|c|}{ Based the results of the }
\end{tabular}

regression test above, the following mathematical equations can be arranged:

$\mathrm{Y}=1.861+0.086 \mathrm{X} 1+0.142 \mathrm{X} 2+0.114 \mathrm{X} 3+\mathrm{e} \ldots$ (1)

From the above equation shows that the coefficient values for all independent variables are positive. This means that it indicates that the effect of the self-efficacy, time budget pressure, and audit experience variables is directly proportional to the audit judgment variable.

The table above also shows that the variables of self-efficacy, time budget pressure, and audit experience show a significant influence on audit judgment. This can be seen from the probability value which is smaller than 0.05 , where the probability value for self-efficacy is 0.000 , time budget pressure is 0.029 , and for audit experience is 0.004 . These results indicate that all independent variables have a significant positive effect on the dependent variable.

B. The results of the analysis with moderating variables

\begin{tabular}{|c|c|c|c|c|}
\hline Variabel Independen & Koefisien & $\mathrm{t}$ & Sig. & Keterangan \\
\hline Konstanta & $-12,422$ & -919 & & \\
\hline $\mathrm{X} 1 . \mathrm{Z}$ & $-0,028$ & -994 & 0,324 & $\begin{array}{c}\text { Tidak } \\
\text { Signifikan }\end{array}$ \\
\hline $\mathrm{X} 2 . \mathrm{Z}$ & 0,082 & 2,346 & 0,023 & Signifikan \\
\hline $\mathrm{X} 3 . \mathrm{Z}$ & $-0,052$ & $-2,059$ & 0,044 & Signifikan \\
\hline $\begin{array}{c}\alpha=5 \%=0,05 \\
\text { R square }=0,670\end{array}$ & & & & \\
\hline
\end{tabular}

regression test after interacting with the task complexity variable $(\mathrm{Z})$, the mathematical equations can be arranged as follows:

$\mathrm{Y}=-12.422-0.028 \mathrm{X} 1 . \mathrm{Z}+0.082 \mathrm{X} 2 . \mathrm{Z}-0.052 \mathrm{X} 3 . \mathrm{Z}+$ e... (2)

From the table above, it can be seen that after the self-efficacy variable interacts with task complexity (moderation) it has a probability value of 0.324 above the significant standard value of 0.05 . This shows that it shows that the task complexity variable is not able to moderate the effect of self-efficacy on audit judgment.

In the interaction of time budget pressure with task complexity (moderation) it has a probability value of 0.023 below the standard value of 0.05 significant. This shows that task complexity is able to moderate the effect of time budget pressure on audit judgment. In the interaction of time budget pressure with task complexity (moderation) it has a probability value of 0.023 below the standard value of 0.05 significant. This shows that task complexity is able to moderate the effect of time budget pressure on audit judgment. The coefficient for the interaction of time budget pressure and task complexity variables is positive 0.082 , which means that the task complexity variable strengthens the effect of time budget pressure on audit judgment.

Furthermore, the audit experience variable interacting with task complexity (moderation) has a probability value of 0.052 below the significant standard value of 0.05 . This shows that task complexity is able to moderate the effect of audit experience on audit judgment. The coefficient for the interaction of the audit experience variable and task complexity is negative -0.052 , which means that the task complexity variable weakens the effect of audit experience on audit judgment.

\section{DISCUSSION}

A. Self-efficacy affect on Audit Judgment

The test results show that the proposed hypothesis is accepted. Thus, the hypothesis that self-efficacy has a positive influence on audit judgment is empirically proven. So this can be obtained in a positive direction. This shows that the greater the self-efficacy of an auditor in carrying out their duties in auditing, the greater the impact on the judgment they make. The results of this study are in line with the results of research conducted by Suweknyo (2016) which states that self-efficacy has a significant influence on audit judgment. 
This is also said by Suardhika and Budiartha (2017) and Santi (2019) which state that self-efficacy has a positive and significant influence on audit judgment.

\section{B. Time Budget Pressure affect the Audit Judgment}

The test results show that the proposed hypothesis is accepted, so the hypothesis that audit time budget pressure has a positive effect on audit judgment is empirically proven. This shows that the higher the audit time budget pressure that an auditor has in carrying out his duties does not affect the auditor to produce an inaccurate audit judgment. The pressure of a very limited time budget does not change the professionalism of the auditor in making the right judgment. Research conducted also by Agustini and Merkusiwati (2016) stated that time budget pressure has a positive and significant effect on audit judgment

\section{Audit Experience Affects Audit Judgment}

The results showed that the proposed hypothesis was accepted. Thus, the hypothesis that audit experience has a significant influence on audit judgment is empirically proven. So this can be obtained in a positive direction. This shows that the more audit experience an auditor has in carrying out their duties, the better judgment can be produced. The results of this study are in line with those of Chotimah and Kartika (2017) which state that audit experience has a positive and significant effect on audit judgment.

\section{Task Complexity Moderates the effect of Self-efficacy on Audit Judgment}

The results of this study indicate that the proposed hypothesis is rejected. This means that task complexity has not been able to moderate the relationship between self-efficacy and audit judgment. This finding indicates that task complexity weakens the effect of self-efficacy on audit judgment. The results of this study are in line with Yulvana's research (2018) which states that the task complexity variable has not been able to moderate the effect of selfefficacy on audit judgment.

\section{E. Task Complexity Moderates the effect of Time Budget Pressure on Audit Judgment}

The results of this study indicate that the proposed hypothesis is accepted. Thus the hypothesis which states that time budget pressure has a significant effect on audit judgment is empirically proven. In this case also obtained a positive direction. It can be explained that the complexity of the task strengthens the effect of time budget pressure on audit judgment. This is supported by research conducted by Nirmala (2017). The results of this study are also in line with research conducted by Nugraha and Indira (2015) which states that the task complexity variable is able to moderate the effect of time budget pressure on audit judgment.

\section{F. Task Complexity Moderates the influence of Audit Experience on Audit Judgment}

The results of this study indicate that the proposed hypothesis is accepted. This means that task complexity moderates the relationship between audit experience and audit judgment. The finding also shows that task complexity significantly strengthens the effect of audit experience on audit judgment. This shows that the high complexity of the task strengthens the effect of audit experience on the audit judgment of the Inspectorate of West Sulawesi Province auditors.

\section{CONCLUSION}

Self-efficacy positive effect on audit judgment. This is in line with the view of social cognitive theory which assumes that high self-confidence in an individual in carrying out a particular task will affect his personal activities in achieving his own goals better.

Time budget pressure positive effect on audit judgment. This shows that the higher the audit time budget pressure that an auditor has in carrying out his duties in 
Jenny Tandean et.al. The effect of self efficacy, time budget pressure and audit experience on audit judgment with task complexity as moderating variable

auditing will increase the judgment they make.

Audit experience has a positive effect on audit judgment. This means that auditors with a high level of experience will be more sensitive and easier in carrying out their duties and produce better audit judgment

Task complexity has not been able to moderate the relationship between selfefficacy and audit judgment. It can be interpreted that the higher the complexity of the task, the lower the effect of self-efficacy on audit judgment.

The complexity of the task moderates and strengthens the relationship between time budget pressure and audit judgment. In this case, the high complexity of the task and the time budget pressure obtained are things that are able to hinder an auditor in producing professional judgment.

The complexity of the task moderates and strengthens the relationship between audit experience and audit judgment. The high complexity of the task and the high audit experience gained are things that can produce professional judgment.

\section{Acknowledgement: None}

\section{Conflict of Interest: None}

\section{Source of Funding: None}

\section{REFERENCES}

1. Agustini dan Merkusiwati (2016). Pengaruh tekanan ketaatan, senioritas auditor dan tekanan anggaran waktu terhadap audit judgment. ISSN: 2302-8556E-Jurnal Akuntansi Universitas Udayana Vol.15.1: 433-462

2. Bandura. (1977). Self-efficacy: Toward a Unifying Theory of Behavioural Change. 191215.

3. Chotimah, C. dan Kartika. A. (2017). Pengaruh Gender, Tekanan Ketaatan, Kompleksitas Tugas, dan Pengalaman Auditor terhadap Audit Judgment. Dinamika Akuntansi Keuangan dan Perbankan. Vol. 6. No. $1: 1-16$.
4. Nirmala \& Nur. (2013). Pengaruh independensi, pengalaman, due professional care, akuntabilitas, kompleksitas audit, dan time budget pressure terhadap kualitas audit. Vol 2 No.3(2337-3806), 1-13.

5. Nirmala \& Made. (2017). Kompleksitas tugas sebagai pemoderasi Fakultas Ekonomi dan Bisnis Universitas Udayana ( Unud ), Bali , Indonesia .19, 683-711.

6. Nugraha, A. P., dan J. Indira. (2015). Pengaruh Gender, Pengalaman, Keahlian Auditor, dan Tekanan Ketaatan terhadap Auditor Judgment dengan Kompleksitas Tugas sebagai Variabel Moderasi pada BPK RI Jawa Tengah. Diponegoro Journal of Accounting. Vol. 4. No. 4 : 1-11

7. Puspitasari. (2011). Analisis faktor-faktor yang mempengaruhi penggunaan informasi akuntansi keuangan terhadap penerapan pencatatan laporan keuangan pada usaha mikro. 13-93.

8. Suweknyo, A. (2016). Pengaruh Tekanan Ketaatan, Kompleksitas Tugas, Pengetahuan, Persepsi Etis dan Self Efficacy terhadap Audit Judgment. Fakultas Ekonomi dan Bisnis. Universitas Mumahammdiyah Surakarta.

9. Suardhika, I.M.S. dan Budiarha. K. (2017). Kemampuan Gender memoderasi Pengaruh Self Efficacy dan Kompleksitas Tugas pada Audit Judgment. FEB Unud. Vol. 12. No. 2: 107-121.

10. Tan, Tong Han dan Alison Kao.1999.Accountability Effect on Auditor's Performance: The Influence of Knowledge, Problem Solving Ability and Task Complexity: Journal of Accounting Reseach 2:209-223.

11. Yulvana (2018). Kompleksitas tugas sebagai pemoderasi pengaruh orientasi tujuan dan self efficacy pada audit judgment (studi empiris pada Kantor Akuntan Publik di Bali).

12. Yusrianthe. (2015). Analisis Faktor - Faktor Yang Mempengaruhi Audit Delay Pada Perusahaan Manufaktur Yang Terdaftar Di Bursa Efek Indonesia. Jurnal Akuntansi, XIX(1), 50-67.

How to cite this article: Tandean J, Pagalung G, Syamsuddin. The effect of self efficacy, time budget pressure and audit experience on audit judgment with task complexity as moderating variable. International Journal of Research and Review. 2022; 9(1): 372-377. DOI: https:// doi.org/10.52403/ijrr.20220144 